\title{
Surveillance of mosquito larvae (Diptera: Culicidae) in microhabitats of a University Campus in Southwestern Nigeria
}

\author{
Babatunde Amusan ${ }^{1}$ (D) \& Sylvestre Ogbogu ${ }^{1}$ \\ 1. Obafemi Awolowo University, Department of Zoology, Ile - Ife, Osun, Nigeria; tundeamusan5@yahoo.com; \\ slyd58@yahoo.com
}

Recibido 19-VIII-2019 • Corregido 6-XI-2019 • Aceptado 12-XII-2019

DOI: https://doi.org/10.22458/urj.v12i1.2605

\begin{abstract}
Introduction: Mosquitoes, vectors of vital diseases, are among the most deadly animals in the world. Their faunistic composition and prevalence of these mosquitoes are dependent on the characteristics of larval habitats. Objective: To determine how habitats influence the composition, abundance and distribution of the mosquito larvae on Obafemi Awolowo University, Ile - Ife campus. Methods: We sampled larvae monthly between 07: 00 and 10:00 (August, 2017 - January, 2019) using a standard dipping method. The microhabitats included ground pools, discarded containers, drainage channels and tree holes in each of the study sites. Results: We identified seven species distributed in three genera: Anopheles spp. (Anopheles gambiae, Anopheles funestus); Aedes spp. (Aedes aegypti, Aedes albopictus); Culex sp (Culex pipiens, Culex quinquefasciatus, Culex poicilipe). Culex was the dominant and most abundant genus (48\%). Larvae were significantly $(p<0,05)$ more abundant in the dry season. The highest abundance of mosquitoes was recorded in Akintola Hall $(50,1 \%)$ and drainage channels were the main microhabitat. Location suggests that these species have affinity for humans and their dwellings. Conclusion: We recommend elimination of breeding sites (un-kept drainage channels, leakages and discarded domestic containers).
\end{abstract}

Keywords: Mosquitoes, Abundance, Distribution, Microhabitats, Prevalence, University.
RESUMEN. "Vigilancia de larvas de mosquito (Diptera: Culicidae) en varios microhábitats en un campus universitario en el suroeste de Nigeria". Introducción: Los mosquitos, vectores de enfermedades vitales, son considerados como uno de los animales más mortales del mundo. La composición faunística y la prevalencia de estos mosquitos dependen de las características de los hábitats de larvas. Objetivo: Determinamos cómo los hábitats influyen en la composición, abundancia y distribución de las larvas de mosquito en la Universidad Obafemi Awolowo, campus de lle-Ife. Métodos: Realizamos el muestreo de larvas de mosquito mensualmente entre las 07:00 y las 10:00 (agosto de 2017 a enero de 2019) utilizando el método de inmersión estándar. Incluimos varios microhabitats en el muestreo como charcos, contenedores desechables, canales de drenaje y tres agujeros en cada sitio de studio. Resultados: Identificamos siete especies distribuidas en tres géneros: Anopheles spp. (Anopheles gambiae, Anopheles funestus); Aedes spp. (Aedes aegypti, Aedes albopictus); Culex spp. (Culex pipiens, Culex quinquefasciatus, Culex poicilipe). Culex fue el género dominante y más abundante (48\%). Las larvas de mosquito fueron significativamente $(p<0,05)$ más abundantes en la estación seca. La mayor abundancia de mosquitos se registró en Akintola Hall $(50,1 \%)$ y los canales de drenaje fueron el microhabitat con mayor abundancia de mosquitos. Conclusiones: Recomendamos la eliminación de sitios de reproducción (canales de drenaje sin mantenimiento, fugas y contenedores domésticos desechados).

Palabras clave: mosquitos, abundancia, distribución, microhábitats, prevalencia, universidad. 
Over the years, mosquito infestation has been a major public health concern in Nigeria. Infact, mosquitoes have been implicated for the transmission of important diseases such as; Malaria, Filariasis, Yellow fever, dengue fever etc. These diseases have been reportedly responsible for the death of about one billion people yearly (WHO, 2014). Little wonder the mosquitoes have been described as the deadliest creature on earth (WHO, 2015). The high prevalence of mosquitoes has impacted the social well-being of individuals living in such areas of high prevalence by the diseases transmitted by the mosquitoes (Amiruddin, Sidik, Alwi, Islam, \& Astuti, 2012). Furthermore, malaria and these other diseases vectored by mosquitoes has been identified as one of the leading causes of childhood and maternal morbidity, low productivity and reduced school attendance in Nigeria. Although, there has been improvement in health facilities in most developing countries and this is expected to yield a corresponding reduction in the transmission of malaria but on the contrary, the disease persists in several African cities. In fact, the prevalence is much higher in the urban areas than in the rural areas (Mbanugo \& Okpalaononuju, 2013).

Climatic and environmental variables have been identified as major factors influencing the distribution of mosquitoes in the environment (Amusan, 2004). Also, it has been discovered that the vectoral capacity of mosquitoes for the transmission of diseases is dependent on the rate of larval production from the breeding habitats (Depinay, Mbogo, Killeen, Gnols, \& Carlson, 2004). Mosquitoes have not only shown preference for all sorts of stagnant water, they are also known to require only a few tablespoons of water to breed. As a result, tyres, ponds, ground pools, streams erosion pits, leaking pipes, tree holes and discarded containers have been mentioned as important breeding sites for mosquitoes. Environmental factors such as temperature, rainfall and humidity are also considered essential in the duration of mosquito development and longetivity. For instance, temperature is regarded as the most important factor as it is responsible for variations in the maturation period of the mosquito larva while rainfall does not only affect relative humidity, it also increases the available breeding sites (Ojo \& Mafiana, 2001).

Surveys and collection studies have been identified as important steps in the determination of the risks involved with diseases and possibly the development of control and mitigating plans for vector-borne diseases. In Nigeria, previous studies on the distribution and diversity of mosquitoes larvae have revealed Anopheles, Aedes, Culex and Mansonia as the commonly encountered group of mosquitoes in the country. These genera have been listed among the deadly mosquitoes in Africa (WHO, 2014). This is the essentiality of the study of the ecology of this important group of insects. This study therefore seeks to provide information on the abundance, distribution and ecology of the various mosquitoes within the selected microhabitats on Obafemi Awolowo University, Ile-Ife campus. This study will further seek to ascertain if the environmental factors associated with the microhabitats are important for the accurate predictions of the occurrence of mosquitoes. The information provided here-in will be useful in planning more effective vector control strategies.

\section{METHODOLOGY}

Study Area: The study was conducted within the campus of Obafemi Awolowo University, Ile-Ife, Osun State, Nigeria. The University lies between $07^{\circ} 31^{\prime} 14.76^{\prime \prime} \mathrm{N} \& 04^{\circ} 31^{\prime} 49^{\prime \prime} \mathrm{E}$. The total land mass is about 5,605 hectares. The area stands at an average height of 300masl with an average altitude of $1200 \mathrm{~m}$. Ile - Ife receives about $1500 \mathrm{~mm}$ of rainfall annually and the ambient temperature ranges between $20^{\circ} \mathrm{C}$ and $30^{\circ} \mathrm{C}$ with a mean of $27^{\circ} \mathrm{C}$ (Komolafe \& Arawomo, 2008). The campus community has rich vegetation typical of tropical rainforest belt and grassland with few swampy areas. The major source of water within the University campus is Opa reservoir which provides potable water and other ancillary functions to the University community. Apart from the reservoir, 
there are other streams and ground pools with intermittent flows. These ground pools are usually stagnant and conducive for breeding of mosquitoes especially during the dry season.

Study sites: Three different locations within the campus were selected for mosquito larvae sampling. The Study sites selected include; Akintola Hall (A residential hostel), BOO park (A semiforest) and Opa reservoir (The University water scheme area). These study sites are characterized by different vegetation gradient and they are located about $4 \mathrm{~km}$ apart.

\section{Ecological description of the study sites}

Akintola Hall: This study site comprised a student hostel which accommodates about 1400 students living in eight blocks of three storey building. The site is surrounded by tall trees, shrubs and abundant grasses. The area is characterized by numerous leaking pipes, drainage channels and patched of ground pools with stagnant water. A stream named Aho stream runs through the back of the hostel.

Boo Park: This is a semi-forested area located close to the academic area of the University campus. There are lots of tall trees forming dense canopies in the area. This area is also characterized by varieties of ornamental plants. Lots of tree holes, ground pools, and patches of stagnant waterbodies are found within this study site.

Opa Reservoir: This area houses the University's water scheme. The reservoir provides potable water and other ancillary functions to the University community. This site is characterized by lots of submerged and terrestrial vegetation. Water treatment tanks, pipes, storex tanks, drainage channels and containers are also in abundance in this study sites.

Sampling Techniques: Mosquito larvae were collected using standard dipping method with a mosquito scoop (Bioquip, Gardena, USA) in the various selected microhabitats. Where dippers could not be used (especially in containers), the content of the containers were emptied into plastic bowls for easy collection of the mosquito larvae (Service, 1993). Larvae sampling was conducted monthly between 07: 00 and 10:00 for six months (August, 2017 - January, 2019) representing three months each of wet and dry seasons. The various microhabitats sampled included; ground pools, discarded containers, drainage channels and tree holes in each of the study sites.

Identification of Mosquito larvae specimens: The collected mosquito specimens were identified to species level by standard identification keys and guides such as Gillet (1972), Oyerinde (1999) and Harbach (2008).

Data analysis: Diversity indices were used to estimate the diversity of mosquito larvae among the study sites. Pearson correlation analysis was used to test the relationship between the mosquito species and the environmental variables recorded. These analyses were done using Patheological Statistics (PAST, Version 3,14).

Ethical, conflict of interest and financial statements: The authors have fully complied with all pertinent and legal requirements both during the study and in the production of the manuscript. We state that there are no conflicts of interest of any kind. The financial sources are fully and clearly stated in the acknowledgements section and we fully agree with the final edited version of the article. A signed document has been filed in the journal archives. 


\section{RESULTS}

A total of 611 individuals of mosquitoes which comprised three genera (Anopheles, Aedes and (Culex) were collected for the entire study period. These three genera were represented by seven species as thus; Anopheles gambiae, Anopheles funestus, Aedes aegypti, Aedes albopictus, Culex pipiens, Culex quinquefasciatus, Culex poicilipes. Culex was dominant over the two other genera as it accounted for $48 \%$ of the total collection while Aedes and Anopheles represented $26 \%$ and $25 \%$ respectively. All the three genera were recorded in all the investigated microhabitats within the study area. Culex pipiens was the dominant mosquito species in the study area as it accounted for the highest number of individuals (159) collected and this represented $26 \%$ of the entire collection. Other species that also occurred in relatively high numbers include; Anopheles gambiae, Aedes aegypti and Culex quinquefasciatus. Culex poicilipes accounted for the least number of individuals (48) and this represented $7,9 \%$ of the entire collection (Table 1 ).

TABLE 1

Abundance and distribution of mosquito larvae in Obafemi Awolowo University, Ile - Ife

\begin{tabular}{lcccc}
\hline \multicolumn{1}{c}{ Mosquito larva species } & \multicolumn{5}{c}{ Study Sites } \\
\hline $\begin{array}{l}\text { Anopheles } \\
\text { Anopheles gambiae }\end{array}$ & 21 & 71 & 11 & 103 \\
$\begin{array}{l}\text { Anopheles funestus } \\
\text { Aedes }\end{array}$ & 17 & 34 & 03 & 54 \\
Aedes aegypti & & & & Opa \\
Aedes albopictus & 50 & 29 & 22 & 101 \\
Culex & 26 & 20 & 13 & 59 \\
Culex pipiens & & & & \\
Culex quinquefasciatus & 63 & 86 & 10 & 159 \\
Culex poicilipes & 31 & 39 & 17 & 87 \\
TOTAL & 15 & 27 & 06 & 48 \\
\hline
\end{tabular}

Amongst the study sites that were investigated, the highest abundance of mosquitoes was recorded in Akintola Hall. A total of $\mathbf{3 0 6}$ mosquito larvae were collected from this study site and this represented $50,1 \%$ of the entire collection. Opa reservoir accounted for 223 mosquito larvae which represented $36,5 \%$ of the total collection while BOO park accounted for the least number of individuals (82) which accounted for $13,4 \%$ of the total collection. Seasonal analysis of the mosquito larvae collection revealed that more larvae were collected in the dry season than in the wet season (Fig. 1).

A total of 330 mosquito larvae were collected in the dry season while 281 were collected in the wet season which represented $54 \%$ and $46 \%$ of the total collection respectively (Table 2 ). It was also observed that significantly higher $(p<0,05)$ number of mosquitoes larvae were recorded in the dry season in the microhabitats sampled except in the leaking pipes where the difference was not statistically significant $(p>0,05)$ (Table 3 ). Investigations further revealed that the highest abundance of mosquito larvae was recorded in the drainage channels as it accounted for 277 ind. (which represented $45 \%$ of the entire collection). Leaking pipes and ground pools accounted for $89(15 \%)$ and $87(14 \%)$ individuals respectively. The least abundance of mosquito larvae was recorded in the Tree holes where 54 (9\%) individuals were collected. 


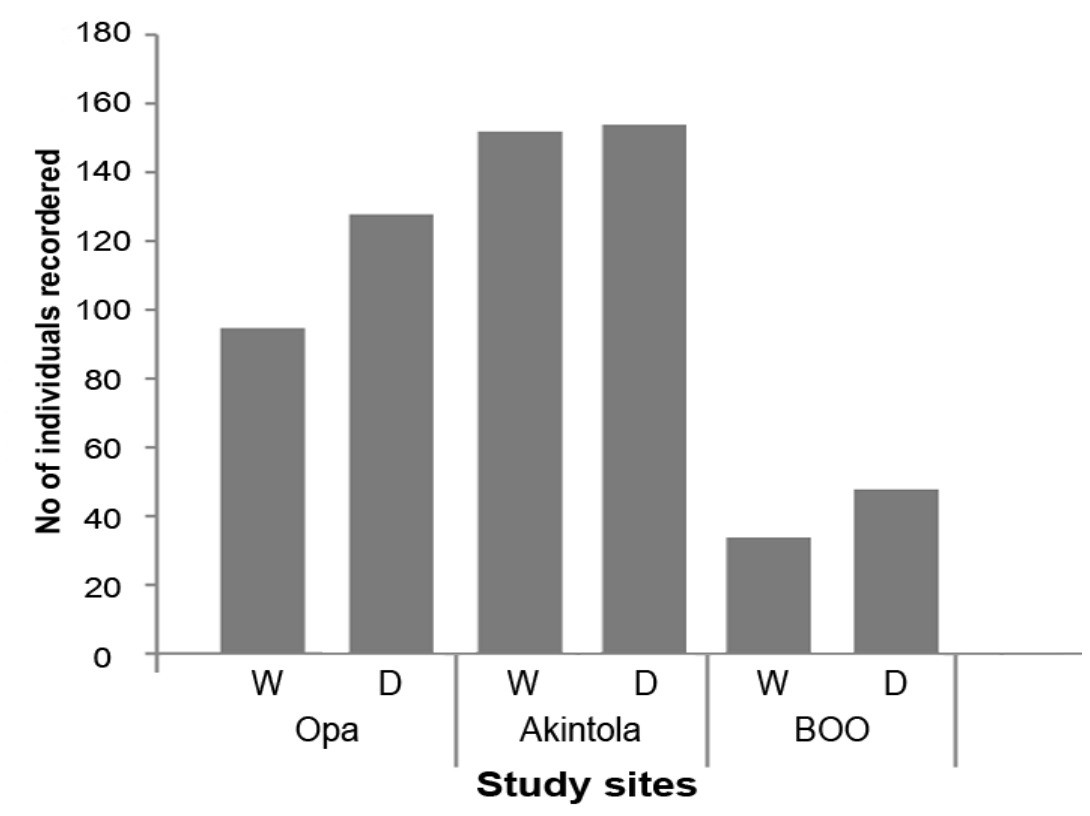

Fig. 1. Seasonal abundance of mosquitoes in Obafemi Awolowo University, lle - Ife (W- WET SEASON; D - DRY SEASON).

TABLE 2

Seasonal abundance of mosquitoes in Obafemi Awolowo University, Ile - Ife

\begin{tabular}{lcccccc}
\hline & \multicolumn{2}{c}{ Opa } & \multicolumn{2}{c}{ Akintola } & \multicolumn{2}{c}{ BOo } \\
Mosquitoes larva species & Wet & Dry & Wet & Dry & Wet & Dry \\
\hline Anopheles gambiae & 9 & 12 & 34 & 37 & 3 & 8 \\
Anopheles funestus & 4 & 13 & 15 & 19 & 1 & 2 \\
Aedes aegypti & 12 & 38 & 12 & 17 & 9 & 13 \\
Aedes albopictus & 11 & 15 & 12 & 8 & 6 & 7 \\
Culex pipiens & 34 & 29 & 49 & 37 & 4 & 6 \\
Culex quinquefasciatus & 16 & 15 & 19 & 20 & 9 & 8 \\
Culex poicilipes & 9 & 6 & 11 & 16 & 2 & 4 \\
\hline
\end{tabular}

TABLE 3

Seasonal abundance and distribution of mosquitoes in the investigated microhabitats in Obafemi Awolowo University, Ile - Ife

\begin{tabular}{lccc}
\hline \multicolumn{1}{c}{ Habitat type } & Wet & Dry & Total (\%) \\
\hline Ground pools & 31 & 56 & $87(14)$ \\
Tree Holes & 21 & 33 & $54(9)$ \\
Household Containers & 38 & 66 & $104(17)$ \\
Leaking Pipes & 41 & 48 & $89(15)$ \\
Drainage Channels & 83 & 194 & $277(45)$ \\
\hline
\end{tabular}




\section{DISCUSSION}

This study revealed that seven species distributed in three genera were contained in the study area as at the study period. This suggests a relatively high diversity of mosquitoes within the study area. This observation is similar to earlier reports such as; Oguoma and Ikpeze (2008), Egbuche, Ezihe, Aribodor, and Ukonze (2016), Onyekachi, Carmelita, Ohaeri, Amaechi, and Collins (2018) and Okwa, Omolade, Savage, and Adetutu (2018) in which similarly high diversity of mosquitoes were recorded within relatively similar landscapes. The high species richness in this study area may be attributed to availability of diversed suitable breeding microhabitats such as domestic containers, drainage channels, leakages, tree holes and ground pools. The availability of suitable microhabitats in the study area is further corroborated by the occurrence and abundance of the seven species in each of the tree study sites (Opa Reservoir, Akintola Hall and BOO Park). The occurrence of all the recorded species in the three study sites suggested that each of the study sites provided suitable breeding habitats for the mosquito species recorded in this study.

Culex was the dominant and most abundant genera in this study. The occurrence of Culex $\mathrm{sp}$ as dominant and most abundant species is not strange as this group of mosquitoes have been reportedly dominant and abundant in studies in different part of the country. Such studies include; Mafiana, Anaeme and Olatunde (1998), Anosike et al. (2007), Onyido, Ezike, Ozumba, Nwankwo, and Nwankwo (2009). According to Farjana, Ahmmed, Khanom, Alam, and Begum (2015) and Okwa et al. (2018), Culex mosquitoes are usually common in polluted waters and sites with foul smells. The high prevalence of Culex in this study area could possibly be attributed to their ability to breed in polluted waterbodies (Mafiana et al., 1998). It is worth noting that the highest abundance of Culex sp was recorded in Akintola Hall, which could be regarded as the dirtiest of the three study sites. This further confirmed the preference of this group of mosquitoes for dirty and polluted habitats.

Aedes also occurred in relatively high number as it accounted for about $26 \%$ of the entire collection. This group of mosquitoes has been known to breed very well in shallow waterbodies and domestic containers (WHO, 2002). Apart from shallow waters, ambient temperature, relative humidity and water quality have also been mentioned as factors that influence the occurrence and abundance of the Aedine mosquitoes in any particular habitat (Chen, Lee, Stella-Wong, Lau, \& Sofian-Azirun, 2009; Dejene, Habte, Teshome, Meshesha, \& Akalu, 2015). Aedes (which is the principal vector of dengue viruses) is known to be closely associated with humans and their dwellings. They are known to breed very well in water holding containers in and around the home (Senthamarai \& Jebanesan, 2016). Little wonder a large number of the Aedes mosquitoes were recorded around Akintola Hall of residence.

Anopheles mosquitoes were recorded in relatively fewer numbers in this study. This is surprising as these mosquitoes have been previously mentioned as dominant and abundant in several mosquito surveys in Nigeria. This dominance has been attributed to their ability to breed successfully in discarded containers and other microhabitats. In fact, Opoku et al. (2007) and Aigbodion and Odiachi (2003) recorded large number of Anopheles mosquitoes in containers and domestic run off. However, Anopheles mosquitoes are known to have preference for cleaner and well oxygenated waters. Therefore, the relatively fewer number of individuals collected in this study may be due to the inadequacy of such clean waterbodies in the study sites.

Overall, more mosquito larvae were collected in the dry season than in the wet season. This observation is similar to the report of Anosike et al. (2007) and Okwa et al. (2018) in which abundance of mosquitoes were greater in the dry season than in the wet season. This observation may be due to the abundance of rainfall in the wet season which has been known to be detrimental to the survival of mosquitoes in the environment. Many larvae and potential breeding sites are washed off by run-off, thus causing a reduction in the population of the mosquitoes in the wet 
season. In the dry season, there are usually more stagnant waters in the environment, which is considered favourable and suitable for the breeding of mosquitoes.

It is also exciting to note that the three identified genera co-breeded in the same habitats as the three genera were recorded in all the microhabitats in the three selected study sites. There were variations in the abundance and distribution in the microhabitats which could be attributed to the differences in environmental conditions or microclimatic variations as well as availability of suitable preferred breeding sites.

This study has provided vital information on the faunistic composition, abundance and distribution of mosquito larvae within Obafemi Awolowo University, lle - Ife Campus. A combination of factors such as indiscriminate disposal of domestic containers, leakages, unkept gutters and drainage channels provided enormous suitable breeding sites for the mosquitoes. Elimination of such mosquito breeding sites can be an effective and sufficient means of abating the prevalence of mosquitoes in the environment.

\section{AKNOWLEDGEMENTS}

We are grateful to the authority of Obafemi Awolowo University, lle - Ife for granting us access to the various locations where the mosquito larvae collections were done.

\section{REFERENCES}

Aigbodion, F. I., \& Odiachi, F. C. (2003). Breeding Sites Preferences of Anopheline Mosquitoes in Benin City, Nigeria. Nigerian Journal of Entomology, 20, 1-7.

Amiruddin, R. D., Sidik, A., Alwi, N., Islam, J. P., \& Astuti, S. (2012). Socioeconomic factors and access to health services for malaria control in Mamuju District, West Sulawesi Indonesia. Asian Journal of Epidemiology, 5, 56-61. DOI: 10.3923/aje.2012.56.61

Amusan, A. A. S. (2004). Distribution of mosquitoes (Diptera: Culicidae) and Disease Transmission Patterns in Ogun State (PhD Dissertation). University of Agriculture, Abeokuta, Ogun State.

Anosike, J. C. B., Nwoke, A. N, Okere, E. E, Oku, J. E, Asor, I. O., Emmy, E., \& Adimike D. A. (2007). Epidemiology of treehole breeding mosquitoes in the tropical rainforest of Imo state, South East Nigeria. Annals of Agricultural Environment and Medicine, 14, 31-38.

Chen, H. L., Lee, S. P., Stella-Wong, K. W., Lau, M., \& Sofian-Azirun, L. (2009). Container survey of mosquito breeding sites in a university campus in Kuala Lumpur, Malaysia, Dengue Bulletin, 33(1), 187-193.

Dejene, G., Habte, T., Teshome, G. M., Meshesha, B., \& Akalu, M. (2015). Breeding Sites of Aedes aegypti: Potential Dengue Vectors in Dire Dawa, East Ethiopia. Epidemic dengue/ dengue hemorrhagic fever as a public health, social and economic problem in the 21st century. Trends of Microbiology, 10, 100-103. DOI: 10.1016/S0966$842 \times(01) 02288-0$

Depinay, J. O., Mbogo, C. M., Killeen, G., Knols, B. J., \& Carlson, J. (2004). A simulation model of African Anopheles ecology and population dynamics for the analysis of malaria transmission. Malaria Journal, 3(29) DOI: 10.1186/14752875-3-29

Egbuche, C. M., Ezihe, C. K., Aribodor, D. N., \& Ukonze, C. B. (2016). Survey of mosquitoes in open and closed larval habitats in Aguleri, Anambra East Local Government Area of Anambra State, South Eastern Nigeria. Journal of Mosquito Research, 17, 1-5. 
Farjana, T., Ahmmed, M.S., Khanom, T. F., Alam, N., \& Begum, N. (2015). Surveillance of Mosquitoes Larva at Selected Areas of Mymensingh District in Bangladesh T. Bangladesh Journal of Veterinary Medicine, 13(1), 79-88. DOI: 10.3329/bjvm.v13i1.23962

Gillet, J. D. (1972). Common African Mosquitoes and their Medical Importance (Vol. I). London, UK: William Heinemann Medical Books Limited.

Komolafe, O. O., \& Arawomo G. A. O. (2008). Preliminary observations on fish species in a newly impounded Osinmo reservoir. Turkish Journal of Fisheries and Aquatic Sciences, 8, 289-282.

Mafiana, C. F., Anaeme, L., \& Olatunde, G. O. (1998). Breeding sites of larval Mosquitoes in Abeokuta Nigeria. Nigerian Journal of Entomology, 15, 136-143.

Mbanugo, J. I., \& Okpalaononuju, C. N. (2013). Survellence of mosquitoes vectors in some habitats of Awka metropolis, Anambra State Nigeria. Journal of Parasitology, 24, 184-190. DOI: 10.4314/njpar.v24i1.37825

Oguoma, V. M., \& Ikpeze, O. O. (2008). Species composition and abundance of mosquitoes of a tropical irrigation ecosystem. Animal Research International, 2, 866-871. DOI: 10.4314/ari.v5i2.48748

Ojo, D. A., \& Mafiana, C. F. (2001). Evaluation of fever in the presumptive diagnosis of malaria endemicity. Nigerian Journal of Parasitology, 22, 35-42.

Okwa, O., Omolade, L., Savage, A., \& Adetutu O. (2018). Oviposition and Breeding Water Sites Preferences of Mosquitoes within Ojo area, Lagos State, Nigeria. Journal of Scientific \& Technical Research, 7(5).

DOI: 10.26717/BJSTR.2018.07.001565

Onyekachi E., Carmelita, C., Ohaeri, E., Amaechi, C., \& Collins N. E. (2018). Distribution and abundance of mosquito larvae in Ohafia, Abia State, Nigeria. Cuadernos de Investigación UNED, 10(2), 379-385. DOI: 10.22458/urj.v10i2.2166

Onyido, A. E., Ezike, V. I., Ozumba, N. A., Nwankwo, A. C. N., \& Nwankwo, E. A. (2009). Yellow fever vectors' surveillance in three satellite communities of Enugu Municipality. The Nigerian Journal Parasitology, 1, 13-17. DOI: 10.4314/ njpar.v30i1.43981

Opoku, A. A., Ansa-Asare, O. D. and Amoako, J. (2007). The occurrence and habitat characterization of some mosquitoes in Accra. West African Journal of Applied Ecology, 11, 99-107.

Oyerinde, J. P. O. (1999). Essentials of Tropical Medical Parasitology. Akoka: University of Lagos Press.

Senthamarai, P. S., \& Jebanesan, A. (2016). Studies on potential breeding habitats of dengue and Chickungunya vector mosquitoes in Ramanathapuram district, Tamil Nadu, India. Indian Journal of Natural Products \& Resources, 73, 234-239.

Service, M. W. (1993). Mosquito Ecology. Field sampling methods. United Kingdom: Elsevier Science Publishers. DOI: 10.1007/978-94-015-8113-4

WHO. (2002). Dengue Fever and Dengue Haemorrhagic Fever Prevention and Control. Geneva: WHO.

WHO. (2014). World malaria Report. Geneva: WHO.

WHO. (2015). Global strategy for Dengue prevention and control. Geneva: WHO. 